\title{
Transient turbid water mass reduces temperature-induced coral bleaching and mortality in Barbados
}

Hazel A Oxenford, Henri Vallès

Global warming is seen as one of the greatest threats to the world's coral reefs, and with continued rise in sea surface temperature predicted into the future, there is a great need for further understanding of how to prevent and address the damaging impacts. This is particularly so for countries whose economies depend heavily on healthy reefs, such as those of the eastern Caribbean. Here, we compare the severity of bleaching and mortality for five dominant coral species at six representative reef sites in Barbados during the two most significant warm-water events ever recorded in the eastern Caribbean, i.e. 2005 and 2010, and describe prevailing island-scale sea water conditions during both events. In so doing, we demonstrate that coral bleaching and subsequent mortality were considerably lower in 2010 than in 2005 for all species, irrespective of site, even though the anomalously warm water temperature profiles were very similar between years. We also show that during the 2010 event, Barbados was engulfed by a transient dark green turbid water mass of riverine origin coming from South America. We suggest that reduced exposure to high solar radiation associated with this transient water mass was the primary contributing factor to the lower bleaching and mortality observed in all corals. We conclude that monitoring these episodic mesoscale oceanographic features might improve risk assessments of southeastern Caribbean reefs to warm-water events in the future. 
1 Transient turbid water mass reduces temperature-induced

2 coral bleaching and mortality in Barbados

3 Hazel A. Oxenford ${ }^{1}$, Henri Vallès ${ }^{2}$

$4 \quad{ }^{1}$ Centre for Resource Management and Environmental Studies, University of the West Indies, Cave Hill,

5 Barbados

6 'Department of Biological and Chemical Sciences, University of the West Indies, Cave Hill, Barbados

7 Corresponding Author:

8 Hazel A. Oxenford ${ }^{1}$

9 CERMES, University of the West Indies, Cave Hill Campus, P.O. Box 64, St Michael, BB11000, Barbados

10 Email address: hazel.oxenford@cavehill.uwi.edu 
12 Abstract

13 Global warming is seen as one of the greatest threats to the world's coral reefs, and with continued rise in sea surface temperature predicted into the future, there is a great need for further understanding of how to prevent and address the damaging impacts. This is particularly so for countries whose economies depend heavily on healthy reefs, such as those of the eastern Caribbean. Here, we compare the severity of bleaching and mortality for five dominant coral species at six representative reef sites in Barbados during the two most significant warm-water events ever recorded in the eastern Caribbean, i.e. 2005 and 2010, and describe prevailing island-scale sea water conditions during both events. In so doing, we demonstrate that coral bleaching and subsequent mortality were considerably lower in 2010 than in 2005 for all species, irrespective of site, even though the anomalously warm water temperature profiles were very similar between years. We also show that during the 2010 event, Barbados was engulfed by a transient dark green turbid water mass of riverine origin coming from South America. We suggest that reduced exposure to high solar radiation associated with this transient water mass was the primary contributing factor to the lower bleaching and mortality observed in all corals. We conclude that monitoring these episodic mesoscale oceanographic features might improve risk assessments of southeastern Caribbean reefs to warm-water events in the future.

\section{Introduction}

31 Coral reefs across the Caribbean have shown significant losses in live coral cover over the last

32 five decades, even though the decline has been spatially and temporally variable (Pandolfi et al. 
33

34

2003; Jackson et al. 2014). These changes have largely been driven by local stressors, especially overfishing and deterioration of water quality (Rogers, 1985; Pandolfi et al. 2003; Jackson et al. 2014), which have reduced the innate resilience of these complex communities. As such, we have witnessed increased levels of coral disease (Aronson \& Precht, 2006) and substantial shifts to low relief, algal dominated reefs in many locations (Done, 1992; Hughes, 1994; Alvarez-Filip et al., 2009). These shifts have been accompanied by significant changes in ecosystem structure and function (Done, 1992; Mumby \& Steneck, 2008). This pattern of degradation is now being exacerbated by climate variability and change, which is expected to accelerate coral reef declines across the region over the coming decades (McWilliams et al., 2005; Anthony et al., 2011; Pandolfi et al., 2011).

An evaluation of the mass bleaching response and subsequent high mortality of coral that occurred in Barbados (Oxenford et al., 2008; Oxenford, Roach \& Brathwaite, 2010), in common with other islands throughout the eastern Caribbean (Wilkinson \& Souter, 2008; Eakin et al., 2010), as a result of the anomalous ocean warming event in 2005 , demonstrated the substantial damage that can be caused by a single climatic event. It also highlighted the importance of understanding the reef response to subsequent warm water anomalies in order to predict impacts and future risk, especially given that the most recent projections indicate increased incidences and severity of sea surface temperature hotspots in the region (Nurse \& Charlery, 2016; van Hooidonk et al., 2015).

Here we compare the bleaching and mortality responses of five dominant coral species in Barbados, across three shallow and three deep reefs, observed during the two most significant 
54 warm-water events ever recorded in the eastern Caribbean, i.e. 2005 and 2010, and we

55

56

57

58

59

60

61

62

63

64

65

66

67

68

69

70

71

72

73

describe the prevailing sea water conditions at the time of the two events. Our main objective is two-fold: (1) to evaluate how corals responded to consecutive anomalous warming events and, (2) to shed light on the potential role of sea water conditions in mediating the response.

\section{Methods}

\section{Benthic surveys}

Quantitative benthic surveys were conducted at six reef sites on the semi-exposed southwest and sheltered west coasts of Barbados ( 3 shallow at $<10 \mathrm{~m}$ and 3 deep at $>15 \mathrm{~m}$ ), representing the typical range of reef habitats in Barbados (fringing, patch and bank reefs; Brathwaite, Oxenford \& Roach, 2008; Figure 1). Further details (GPS coordinates, exact depths, coral cover) can be found in Oxenford et al. (2008). For each of the two anomalously warm summers (2005, 2010), surveys were initiated during the period of highest water temperatures (September/October) and were subsequently repeated every four months (in February and June) through the following year. At each site during each survey, five haphazardly placed $20 \mathrm{x}$ $1 \mathrm{~m}$ belt transects were surveyed by SCUBA divers. Within each transect all coral colonies were identified to species, counted and classified as either fully bleached (living colony with complete loss of tissue coloration) or not fully bleached (living colony with full or partial tissue coloration). Given the large number of coral species concurrently examined, this index of bleaching was used to minimize the risk of subjective differences in appreciation of partial bleaching levels among divers and within divers over time. We also recorded the percent of a 
74 colony's surface that had died recently (i.e. recent dead = exposed white skeleton or light

75 covering with green turf algae).

76 The study species

77 To assess the consistency of the coral response between warm-water events across sites and coral species, we focused on the five most abundant coral species that occurred at all sites, i.e. the species with the five highest average ranks in overall (across surveys) colony abundance across sites. These species together represented more than two thirds (69\%) of all coral colonies surveyed and each species had a cumulative frequency of more than 1,900 colonies examined. The selected corals included a single pioneering 'weedy' species (Porites astreoides) and four climax reef-building 'boulder' corals (Orbicella annularis, Montastraea cavernosa, Diploria strigosa and Siderastrea siderea). Note that Orbicella annularis likely represents a complex of the three very similar species (O. annularis, $O$. franksi and $O$. faveolata) since they could not be reliably distinguished in different environments. The relative importance of the dominant coral species across the different reef sites varied considerably among the three shallow sites, representing different reef habitats, but was similar across the three deep bank reef sites (Figure 1).

Sea water environmental data

91 In situ benthic water temperatures were recorded every $4 \mathrm{~h}$ using onset ${ }^{\circledR} \mathrm{HOBO}^{\circledR}$ Water

92 Temperature Pro v2 Data Loggers placed among the corals at three of the reef sites (Batts Rock,

93 Atlantis and North Bellairs). However, since the temperature profiles from all our loggers were

94 virtually identical (see Oxenford et al., 2008), we have used the logger data from the site with 
95 the longest uninterrupted series (i.e. Batts Rock), for which the data are available from June

962005 onward. Computed mesoscale (50 km grid) degree heating week (DHW) data (Liu et al.,

97 2006) were accessed from the archived NOAA/NESDIS Coral Reef Watch database at

98 http://coralreefwatch.noaa.gov/satellite/vs/data timeseries/vs ts Barbados.txt and are available from November 2000 onward. Satellite-derived data on coloured dissolved organic matter index (CDOM), particulate organic carbon concentration (POC) and chlorophyll-a concentration were obtained from the MODIS-Aqua $4 \mathrm{~km}$ dataset via NASA's Ocean Color

Giovanni site at http://gdata1.sci.gsfc.nasa.gov/daac-bin/G3/gui.cgi?instance id=ocean month.

These data are available from July 2002 onward. We also obtained data on daily current velocity in 2005 and 2010 from the Coastal Zone Management Unit, Government of Barbados, collected by S4 current meters (InterOceans Systems Inc.) at one west coast and one south coast site (Figure 1). These data are available from 2004 but exhibit large gaps in the time series.

\section{Analyses}

For each coral species at each site, we quantified the bleaching response as the proportion of fully bleached colonies per $20 \mathrm{~m}^{2}$ transect. Furthermore, for each coral species at each site, we quantified coral tissue mortality as percent recently dead tissue per colony per $20 \mathrm{~m}^{2}$ transect.

112 For each coral species, we assessed differences in response in bleaching and tissue mortality between warm-water events using a median test based on spatially restricted permutations of

114 the data. We used the median test, a simple yet robust non-parametric test (Sprent \& Smeeton, 115 2001), because our bleaching and tissue mortality data exhibited large numbers of zeros (68\% 
116 and $45 \%$ of the overall transect observations, respectively). The testing procedure involved,

117 firstly, assessing the extent to which the median (bleaching and tissue mortality) response

118 differed between events by running the test with the transect data combined across sites to

119 yield an overall chi-square value. Then, we re-ran the test ten thousand times while randomly

120 shuffling the data between both events at each time, but restricted the data shuffling to take

121 place within sites only so as to account for the fact that the data came from different sites. The

122 latter produced a unimodal frequency distribution of pseudo chi-square values $(n=10,000)$

123 expected under the null hypothesis (i.e. $\mathrm{H}_{\mathrm{o}}$ : no difference between events), which accounted

124 for the spatial structure of the data. Finally, we assessed the probability that the overall chi-

125 square value obtained in the first step (with the original data) came from the distribution of

126 pseudo-chi-square values produced by the spatially restricted permutations (Manly, 1991). If

127 the probability of this value was considered too low (i.e. $p<0.05$ ), we rejected the null

128 hypothesis and considered the response variable to have differed significantly between events

129 for a given coral species. This testing procedure was repeated for each coral species for each

130 monitoring period. This implied that we ran the test 15 times ( 5 coral species $\times 3$ monitoring

131 periods) for the bleaching response and ten times ( 5 coral species $\times 2$ monitoring periods) for

132 the tissue mortality response. To minimize type I errors due to multiple tests, we adjusted p-

133 values using sequential Bonferroni corrections (Holm, 1979) for each separate response

134 variable. These analyses were conducted in the R environment (R Core Team, 2014).

\section{Results}

136 Bleaching response 
137 The bleaching response to the 2005 warm-water event showed a remarkably similar temporal

138 pattern across all five coral species at the six reefs, with a very high proportion of colonies

139 bleaching during the period of highest water temperatures (September/October), a

140 considerably reduced proportion of bleached corals four months later (February) and almost

141 none by June (Figure 2, Table 1).

142 Likewise the bleaching response to the 2010 warm-water event also showed a similar temporal

143 pattern across all five coral species at the six reefs, with the highest proportion of colonies

144 bleaching in September/October and very low levels of bleaching being recorded during the

145 following year through February and June (Figure 2, Table 1).

146 However, a comparison of the coral bleaching response between the 2005 and 2010 events

147 indicated substantial differences in the magnitude of bleaching (Figure 2). Indeed, the initial

148 coral bleaching response was considerably less severe in the second event (2010). In all but a

149 single case, the proportion of colonies bleaching for each species at each reef in

150 September/October 2010 was less than half that recorded in the previous event

151 (September/October 2005). Also, the proportion of colonies still bleached in the following

152 February 2011 was in all cases either lower or the same as in February 2006, whilst there was

153 little difference in the low levels of bleaching recorded in the following June of each event.

154 These observations are confirmed by median tests comparing the intensity of bleaching

155 between both events, which show highly significant differences for all five species in

156 September/October ( $p=0.0015$ in all cases), for two species in February (O. annularis, $p=0.0396$;

157 P. astreoides, $p=0.0496)$, and just one species in June (O. annularis, $p=0.0360$ ) (Table 1$)$. 
158 Tissue mortality response

159 The coral tissue mortality response that followed the peak period of bleaching also exhibited a

160 similar temporal pattern among the five coral species at the six reefs for the 2005 event, with a

161 relatively low proportion of dead coral tissue being recorded in February 2006 and a

162 considerably higher proportion of dead coral tissue being recorded in June 2006 (Figure 3, Table $1632)$.

164 There was also a high degree of similarity in temporal patterns of coral tissue mortality among

165 most species at most reefs following the 2010 warm-water event, with very low proportions of 166 dead coral tissue in both February and June 2011. The only exception was S. siderea at two of

167 the six reef sites (Figure 3, Table 2).

168 In line with the finding that coral bleaching was considerably less severe in the second warm-

169 water event (2010) compared with the first one (2005) for all five corals, so too was the post-

170 bleaching tissue mortality response of these five species. In February 2011, the average percent

171 of recently dead coral tissue per colony for each species was the same or slightly less than in

172 February 2006, but by June 2011 it was substantially lower than in June 2006, with the

173 exception of S. siderea at the Coconut Court reef site (Figure 3). Once again these observations

174 are borne out by the median tests showing no significant differences between the events in the

175 intensity of post-bleaching mortality for four of the five species in February (D. strigosa,

$176 p=0.0275$; all other species, $p=0.6840)$, but significant differences for all species by June (Table 177 2). 
179 The in situ water temperature profiles, unprecedented heating stress (satellite-derived degree

180 heating week (DHW) indices) and satellite derived sea surface temperature (SST) profiles

181 experienced by the reefs during both mass bleaching events in 2005 and 2010 are shown in

182 Figures 4 and $5 a$. These profiles indicate similar timing, duration and intensity of the warmwater events in both years, although the 2010 event was slightly more severe with an October mean peak of >10 DHW in 2005 and >11 DHW in 2010 (Figure 4). In contrast to the similar temperature profiles, satellite-derived sea surface indices negatively associated with water clarity, i.e. coloured dissolved organic matter index (CDOM), particulate organic carbon concentration (POC) and chlorophyll-a concentration, differed dramatically between events in the water surrounding Barbados reefs, with unusually high levels (well above the monthly median values for the 2003-2010 period) of CDOM, POC and chlorophyll- $a$ during most of the dark green, turbid water over Barbados reefs during the summer and fall of 2010 (Pilots log,

Atlantis Submarines Barbados Inc.; member's personal record, Barbados Open Water

Swimming Club; anecdotal reports from dive operators; and personal observation, see Figure

6). These satellite-derived data also suggest that the water experienced by the reefs throughout most of the 2005 event was clearer than usual (Figure 5).

In situ data on daily current velocity during the 2005 and 2010 warm-water events at the west and south coast sites were sporadic with only 13 days of overlapping records from both locations in both years, precluding any meaningful statistical comparisons between sites and years (Figure S3). Visual examination of the time series suggests a lack of temporal consistency in current velocity between these two sites. However, it does reveal evidence of sustained 
201 higher current velocity (up to $18.2 \mathrm{~cm} / \mathrm{s}$ ) for the period August-October at the west coast site in

2022010 compared with 2005 (the latter ranging from around 3-9 cm/s) (Figure S3). There is no

203 evidence of concomitant increases in current velocity at the south coast site, although the large

204 data gaps at this site preclude any rigorous conclusion.

\section{Discussion}

206 In this study we compared the bleaching and post-bleaching mortality responses of the dominant coral species in Barbados to two successive anomalous ocean warming events, i.e. 2005 and 2010, and considered a number of environmental factors that may mitigate the impacts of future acute warming events, the latter being expected to increase in frequency and even become annual in Barbados by 2045-50 (van Hooidonk et al., 2015).

We found considerable differences between the two severe warm-water events in the bleaching and mortality response of the dominant coral species; a result that was consistent across all species and reef habitats. In general, the proportion of coral colonies bleaching and the loss of live coral tissue was significantly less in the second event (2010), even though the timing, intensity and duration of both warm-water events were similar or even slightly more

216 severe in 2010.

217 Numerous studies have demonstrated that the mass bleaching and mortality responses of corals to critically high water temperatures vary, somewhat predictably, according to a number of different parameters. One important parameter is the magnitude of thermal stress (Marshall commonly measured using an index of accumulated heat stress, for example the degree 
222 heating week (DHW) index used by NOAA (http://coralreefwatch.noaa.gov/), which assimilates

223 heating stress over the previous 12 -week period. It is generally agreed that mass coral

224 bleaching is evoked when $\mathrm{DHW}=4^{\circ} \mathrm{C}$ heating weeks, and mass mortality will occur when DHW

$225 \geq 8{ }^{\circ} \mathrm{C}$ (Liu et al., 2006). The higher the heating stress above these thresholds, the more severe

226 the response (Eakin et al., 2010). In this case however, the in situ water temperature and the

227 satellite-derived DHW profiles for each event were closely matched and exceeded $10 \mathrm{DHW}$ in

228 both years (even being slightly higher in 2010), negating differences in magnitude of heating

229 stress as a plausible explanation for the observed differences in the general response of all five

230 dominant coral species.

231 Other parameters influencing susceptibility of corals to heating stress (see West \& Salm, 2003

232 and Baker, Glynn \& Riegl, 2008 for reviews) include inter alia (1) innate differences among coral

233 species (Loya et al., 2001; Baird et al., 2009; Wagner, Kramer \& van Woesik, 2010; Barshis et al.,

2342013 ) as well as differences in the zooxanthellae community they typically host (Berkelmans \&

235 van Oppen, 2006; LaJeunesse et al., 2009; Baums, Devlin-Durante \& LaJeunesse, 2014), (2)

236 differences in colony size (Brandt, 2009; Wagner, Kramer \& van Woesik, 2010); and (3)

237 differences in reef habitats (Marshall \& Baird, 2000; Chollett, Enriquez \& Mumby, 2014). Again,

238 although these factors may partially explain some of the observed variation in response among

239 coral species or among reefs in any given event, they cannot be driving the differences we

240 observed between the two events, since we were monitoring the same group of species over

241 the same depth ranges and habitats (same reef sites) over time and had large sample sizes

242 covering a wide range of colony sizes. Furthermore, although there was some variation in the

243 severity of the bleaching and mortality responses among species in any given event (as 
244

245

246

247

expected), the relative difference in response between the two events was consistent across all species with just one exception (one species at just one of six reef sites in one of three survey periods), and the general response patterns were consistent across all five dominant species.

Bleaching and post-bleaching mortality responses may also be exacerbated by the presence of other chronic local stressors causing synergistic effects (see Wagner, Kramer \& van Woesik, 2010; van Woesik et al., 2012; Ateweberhan et al., 2013 and references therein). The main chronic local stressors on Barbados reefs are eutrophication from land-based activities (Bell \& Tomascik, 1994) and overfishing (Government of Barbados, 2002; McConney 2011), both of which are known to vary among reefs (especially between nearshore shallow and offshore deep reefs). Spatial variability in such stressors may indeed explain observed differences in the severity of responses of single coral species among different reefs in any given event. However, these chronic local stressors have not changed dramatically over the 5-year period between events and are therefore extremely unlikely to be responsible for the difference in responses observed between the 2005 warm-water event and the 2010 one. For example, reef fish landings and number of active reef fishing boats has remained stable in Barbados over the period 1997-2010 (Schuhmann et al., 2011) and water quality data (phosphate and ammonia concentrations) collected at three of our reef sites on the south (Coconut Court) and west (Atlantis and North Bellairs) coasts by the Government's Coastal Zone Management Unit (CZMU) show no consistent trends in eutrophication over the period 2006-2010 (CZMU, unpub. data). 
264 Alternatively, it is possible that the bleaching responses we observed in 2010 were mediated by

265 previous coral experience with warm-water events (Oliver \& Palumbi, 2011; Guest et al., 2012).

266 This 'acclimatization' may occur through a complex variety of mechanisms that include

267 physiological alterations in one or more of the individual partners of the coral holobiont

268 symbioses (coral host, algal symbionts, microbial associates) or changes in the identities or

269 composition of the holobiont's algal and microbial communities (see Baker, Glynn \& Riegl, 2008

270 for review). A study of eight coral species (including all five studied here) on Barbados' reefs

271 during and up to two years after the 2005/2006 bleaching event did indicate algal symbiont

272 'shuffling' and significant increases in the proportion of heat-resistant Symbiodinium trenchi

273 hosted by some species in response to thermal stress (LaJeunesse et al., 2009). However, not all

274 coral species showed significant shuffling of their algal symbionts (namely three of our five

275 species: S. siderea, Diploria spp. and P. astreoides) and those that did increase the proportion of

276 heat resistant symbionts, were found to revert to their original symbiont community within two

277 years of the event (LaJeunesse et al., 2009). Preliminary studies have reported some level of

278 acclimation to heat stress in a single coral species through other physiological mechanisms,

279 namely gene expression (Barshis et al. 2013; Palumbi et al., 2014). However, the corals studied

280 were from an environment in which they were habitually exposed to large fluctuations in

281 temperature associated with the daily tidal cycle, and therefore the results are unlikely to be

282 transferable to corals in our own study which are periodically exposed (e.g. at multiple year

283 intervals) to high temperatures for many weeks at a time. Given this and the fact that the

284 observed symbiont shuffling in our coral species was only temporary (less than 2 years;

285 LaJeunesse et al., 2009), together with the fact that acclimatization or even adaptation is likely 
286 to be highly variable among coral taxa, it seems unlikely that acquired heat tolerance could

287 adequately explain why all five dominant coral species examined were considerably less

288 affected by the 2010 warming event, which occurred five years after the first exposure.

289 We therefore believe that the explanation must lie with one or more factors mediating the

290 ambient environment experienced by all coral species. For example, since a mass bleaching

291 response in corals is elicited through a combination of heating stress and irradiance (Iglesias-

292 Prieto et al., 1992) (see Fitt et al., 2001; Baker, Glynn \& Riegl, 2008 for reviews), a reduction in

293 irradiance could decrease the impact of heating stress (Glynn \& D'Croz, 1990). High solar

294 radiation, particularly photosynthetically active radiation (PAR), disrupts biochemical pathways

295 and damages the photosynthetic apparatus of the symbiotic zooxanthellae, resulting in the

296 production of toxins (oxygen radicals and other detrimental photosynthetic byproducts), which

297 ultimately result in the expulsion of the symbionts from host tissue (Baker, Glynn \& Riegl,

298 2008). Environmental factors that allow for improved flushing of these toxic metabolites that

299 have been found to mitigate bleaching and improve recovery rates include high water current

300 flow under laboratory conditions (Nakamura \& van Woesik, 2001; Nakamura, Yamasaki \& van

301 Woesik, 2003) and associated with upwelling or wind exposure (Bayraktarov et al., 2013).

302 Environmental factors reducing solar radiation that have been reported to reduce the severity

303 of coral bleaching include shading by high islands (West \& Salm, 2003) or in cryptic habitats

304 (Mumby, 1999), cloud cover (Mumby et al., 2001), increased turbidity (Jokiel \& Brown, 2004;

305 Otis et al., 2004; van Woesik et al., 2012) and presence of high levels of aerosols in the

306 atmosphere (Gill et al., 2006), all of which block or scatter and attenuate radiation. In addition,

307 ambient conditions leading to an increase in heterotrophic feeding by the coral host could 
308

309

310 (Wooldridge, 2014).

311 In this case, Barbados and other islands in the eastern Caribbean (see mention by Alemu \&

312 Clement, 2014 and Figures S1 and S2) experienced a significant dark green water mass throughout the summer and fall of 2010. Such green water masses may be experienced in Barbados several times a year due to the episodic passage of North Brazil Current (NBC) rings transporting Amazon River water into the southeastern Caribbean (Fratantoni \& Glickson, 2002). The hydrological effects of these water masses of South American riverine origin on Barbados have been well documented in situ (Table S1). Of particular relevance to this discussion these effects include, changes in water colour associated with a reduction in light penetration, consistent with our own in situ observations (Figure 6), increases in plankton concentration (Borstad, 1979; Kidd \& Sander, 1979), as well as increases in current velocity (Cowen \& Castro, 1994; Stansfield et al., 1995; Paris et al., 2002), with the magnitude of such current velocity increases depending on the angle at which these NBC rings impinge upon the island (Cowen et al., 2003).

We therefore suggest that the coincidental passage of an NBC ring during the warm-water event of 2010 was responsible for reducing overall stress on corals in that year. We posit that the high levels of CDOM, POC and chlorophyll- $a$ observed island-wide, at the time of peak warm temperatures in 2010 (Figure S1) associated with the passage of the NBC ring, was the principle driver in reducing overall stress on corals across all sites by decreasing their exposure to high 
329

330

331

332

333

334

335

solar radiation, thereby ultimately reducing bleaching. We also recognize additional factors associated with the NBC ring that could further contribute to mitigating the impact of a warmwater event including (1) an increase in heterotrophic feeding efficiency by corals in the nutrient rich water, and (2) an increase in toxic metabolite flushing through increases in current velocity. In this case, however, we believe that these additional factors do not adequately account for the consistent patterns across species and sites that we observed. Firstly, heterotrophic feeding plasticity is highly species-specific (Hughes \& Grottoli, 2013; Levas et al., 2015). Secondly, current velocities were mostly well below those reported to benefit corals exposed to high temperatures or recovering from bleaching (i.e. sustained water flow $\geq 20$ cm/s; Nakamura \& van Woesik, 2001; Nakamura, Yamasaki \& van Woesik, 2003) and increases in current velocity in 2010 were not apparent at both west and south coast sites, suggesting the existence of substantial spatial heterogeneity in current structure across Barbados likely resulting from the interaction of the NBC rings with Barbados' bathymetry (Paris et al., 2002).

\section{Conclusion}

In summary, our study supports the idea that temperature-induced coral bleaching and mortality can be moderated by temperature-independent mesoscale hydrological features, as has been suggested in other field studies (Otis et al., 2004; van Woesik et al., 2012; Bayraktarov et al., 2013; Wall et al., 2014).

In Barbados, such mesoscale hydrological features are often associated with the passage of NBC rings (Table S1), thus contributing to the global list of oceanographic phenomena potentially mediating coral responses to climate change. Importantly, our increasingly sophisticated ability 
350 to monitor the NBC ring trajectories from satellites (Fratantoni \& Glickson, 2002) provides a

351 tangible opportunity to increase our capacity to predict the severity of temperature-induced

352 mass coral bleaching and mortality events in Barbados as well as in other southeastern

353 Caribbean islands subject to the same oceanographic phenomena. Overall, better prediction

354 should lead to better policy responses, and repeated coincidence of transient turbid water

355 masses or other mitigating oceanographic features with warm-water events could help buy

356 time for local managers struggling to reduce local stressors to improve reef resilience in the

357 face of climate change.

\section{Acknowledgements}

359 We gratefully acknowledge the SCUBA diving assistance and field data collected by colleagues

360 from: the Coastal Zone Management Unit of the Government of Barbados - A. Brathwaite, R.

361 Roach and F. Hinds; and the University of the West Indies - R. Goodridge, K. Baldwin and C.

362 Finney. 


\section{References}

364

365

366

367

368

369

370

371

372

373

374

375

376

377

378

379

380

381

382

383

384

385

386

387

388

389

390

391

392

393

394

395

396

397

398

399

400

401

402

403

Alemu JB, Clement Y. 2014. Mass coral bleaching in 2010 in the southern Caribbean. PLoS ONE 9: e83829.

Alvarez-Filip L, Dulvy NK, Gill JA, Cote IM, Watkinson AR. 2009. Flattening of Caribbean coral reefs: region-wide declines in architectural complexity. Proc. Roy. Soc. B-Biol. Sci. 276:30193025.

Anthony KRN, Maynard JA, Diaz-Pulido G, Mumby PJ, Marshall PA, Cao L, Hoegh-Guldberg O. 2011. Ocean acidification and warming will lower coral reef resilience. Glob. Change Biol. 17:1798-1808.

Aronson RB, Precht WF. 2006. Conservation, precaution and Caribbean reefs. Coral Reefs 25:441-450.

Ateweberhan M, Fearyb DA, Keshavmurthyc S, Chenc A, Schleyerd MH, Sheppard CRC. 2013. Climate change impacts on coral reefs: Synergies with local effects, possibilities for acclimation, and management implications. Mar. Pollut. Bull. 74:526-539.

Baird AH, Bhagooli R, Ralph PJ, Takahashi S. 2009. Coral bleaching: the role of the host. Trends Ecol. Evol. 24:16-20.

Baker AC, Glynn PW, Riegl B. 2008. Climate change and coral reef bleaching: an ecological assessment of long-term impacts, recovery trends and future outlook. Estuar. Coast. Shelf Sci. 80:435-471.

Bayraktarov E, Pizarro V, Eidens C, Wilke T, Wild C. 2013. Bleaching susceptibility and recovery of Colombian Caribbean corals in response to water current exposure and seasonal upwelling. PLOS ONE 8: e80536. doi:10.1371/journal.pone.0080536

Barshis DJ, Ladner JT, Oliver TA, Seneca FO, Traylor-Knowles N, Palumbi SR. 2013. Genomic basis for coral resilience to climate change. Proc. Natl. Acad. Sci. USA 110:1387-1392.

Baums IB, Devlin-Durante MK, LaJeunesse TC. 2014. New insights into the dynamics between reef corals and their associated dinoflagellate endosymbionts from population genetic studies. Mol. Ecol. 17:4203-4215.

Bell PRF, Tomascik T. 1994. The demise of the fringing coral reefs of Barbados and in regions in the Great Barrier Reef (GBR) lagoon - impacts of eutrophication in Proceedings of the Colloquium on Global Aspects of Coral Reefs: Health, Hazards and History (ed. Ginsburg, R. N.) 319-325. Miami: Rosenstiel School of Marine and Atmospheric Science, University of Miami.

Berkelmans R, van Oppen MJH. 2006. The role of zooxanthellae in the thermal tolerance of corals: a "nugget of hope" for coral reefs in an era of climate change. Proc. R. Soc. $B$ 273:2305-2312.

Borstad GA. 1979. ASTP at Barbados: Mesoscale pools of Amazon River water in the western tropical Atlantic in ASTP Summary Science Report - Vol. II Earth Observations and Photography (eds El-Baz, F. \& Warner, D. M) 481-498. Washington: NASA SP 412.

Brandt ME. 2009. The effect of species and colony size on the bleaching response of reefbuilding corals in the Florida Keys during the 2005 mass bleaching event. Coral Reefs 28, 911-924. 
404

405

406

407

408

409

410

411

412

413

414

415

416

417

418

419

420

421

422

423

424

425

426

427

428

429

430

431

432

433

434

435

436

437

438

439

440

441

442

443

444

445

446

Brathwaite A, Oxenford H, Roach R. 2008. Barbados: a Coral Paradise. Barbados: Miller Publishing, 96pp.

Burke L, Reytar K, Spalding M, Perry A. 2011. Reefs at Risk Revisited. Washington: World Resources Institute.

Chollett I, Enriquez S, Mumby PJ. 2014. Redefining thermal regimes to design reserves for coral reefs in the face of climate change. PLOS ONE 9:e110634.

Cowen RK, Castro LR. 1994. Relation of coral reef fish larval distributions to island scale circulation around Barbados, West Indies. Bull. Mar. Sci. 54: 228-244.

Cowen RK, Sponaugle S, Paris CB, Lwiza KMM, Fortuna JL, Dorsey S. 2003. Impact of North Brazil Current rings on local circulation and coral reef fish recruitment to Barbados, West Indies in Interhemispheric water exchange in the Atlantic Ocean (eds Goni GJ \& Rizzoli PM) 443-462. Amsterdam: Elsevier.

Done TJ. 1992. Phase shifts in coral reef communities and their ecological significance. Hydrobiologia 247:121-132.

Eakin CM, Morgan JA, Heron SF, Smith TB, Liu G, Alvarez-Filip L, Baca B, Bartels E, Bastidas C, Bouchon C, Brandt M, Bruckner AW, Bunkley-Williams L, Cameron A, Causey BD, Chiappone M, Christensen TRL, James M, Crabbe C, Day O, de la Guardia E, Díaz-Pulido G, DiResta D, Gil-Agudelo DL, Gilliam DS, Ginsburg RN, Gore S, Guzmán HM, Hendee JC, HernándezDelgado EA, Husain E, Jeffrey CFG, Jones RJ, Jordán-Dahlgren E, Kaufman LS, Kline DI, Kramer PA, Lang JC, Lirman D, Mallela J, Manfrino C, Maréchal J-P, Marks K, Mihaly J, Miller WJ, Mueller EM, Muller EM, Orozco Toro CA, Oxenford HA, Ponce-Taylor D, Quinn N, Ritchie KB, Rodríguez S, Rodríguez Ramírez A, Romano S, Samhouri JF, Sánchez JA, Schmahl GP, Shank BV, Skirving WJ, Steiner SCC, Villamizar E, Walsh SM, Walter C, Weil E, Williams EH, Woody Roberson K, Yusuf Y. 2010. Caribbean corals in crisis: record thermal stress, bleaching, and mortality in 2005. PLOS ONE 5:e13969.

Fitt WK, Brown BE, Warner ME, Dunne RP. 2001. Coral bleaching: interpretation of thermal tolerance limits and thermal thresholds in tropical corals. Coral Reefs 20:51-65.

Fratantoni DM, Glickson DA. 2002. North Brazil Current ring generation and evolution observed with SeaWiFS. J. Phys. Oceanogr. 32:1058-1074.

Gill JA, Watkinson AR, McWilliams JP, Cote IM. 2006. Opposing forces of aerosol cooling and EI Nino drive coral bleaching on Caribbean reefs. P. Natl. Acad. Sci. USA 103:18870-18873.

Glynn PW, D'Croz L. 1990. Experimental evidence for high temperature stress as the cause of El Nino-coincident coral mortality. Coral Reefs 8:181-191.

Government of Barbados. 2002. A National Biodiversity Strategy and Action Plan for Barbados. Barbados: Ministry of Physical Development and Environment. https://www.cbd.int/doc/world/bb/bb-nbsap-01-en.pdf

Guest JR, Baird AH, Maynard JA, Muttaqin E, Edwards AJ, Campbell SJ, Yewdall K, Amri Affendi $Y$, Ming Chou L. 2012. Contrasting patterns of coral bleaching susceptibility in 2010 suggest an adaptive response to thermal stress. PLOS ONE 7: e33353.

Holm S. 1979. A simple sequentially rejective Bonferroni test procedure. Scand. J. Stat. 6:65-70. Hughes AD, Grottoli AG. 2013. Heterotrophic compensation: a possible mechanism for resilience of coral reefs to global warming or a sign of prolonged stress? PLoS One 8: e81172. 
447

448

449

450

451

452

453

454

455

456

457

458

459

460

461

462

463

464

465

466

467

468

469

470

471

472

473

474

475

476

477

478

479

480

481

482

483

484

485

486

487

488

489

Hughes TP. 1994. Catastrophes, phase-shifts, and large-scale degradation of a Caribbean coralreef. Science 265:1547-1551.

Iglesias-Prieto R, Matta JL, Robins WA, Trench RK. 1992. Photosynthetic response to elevated temperature in the symbiotic dinoflagellate Symbiodinium microadriaticum in culture. $P$. Natl. Acad. Sci. USA 89:10302-10305.

Jackson J, Cramer K, Donovan M, Lam V. (eds). 2014. Status and Trends of Caribbean Coral Reefs: 1970-2012. Switzerland: Global Coral Reef Monitoring Network, IUCN.

Jokiel PL, Brown EK. 2004. Global warming, regional trends and inshore environmental conditions influence coral bleaching in Hawaii. Global Change Biol. 10:1627-1641.

Kidd R, Sander F. 1979. Influence of Amazon River discharge on the marine production system off Barbados, West Indies. J. Mar. Res. 37:669-681.

Kleypas JA, Danabasoglu G, Lough JM. 2008. Potential role of the ocean thermostat in determining regional differences in coral reef bleaching events. Geophys. Res. Lett. 35:L03613, doi:10.1029/2007GL032257.

LaJeunesse TC, Smith RT, Finney J, Oxenford H. 2009. Outbreak and persistence of opportunistic symbiotic dinoflagellates during the 2005 Caribbean mass coral 'bleaching' event. Proc. $R$. Soc. B 276:4139-4148.

Levas S, Baumann J, Grottoli AG, Bauer JE, Schoepf V, Warner ME, Aschaffenburg M. 2015. Can heterotrophic uptake of dissolved organic carbon and zooplankton mitigate carbon budget deficits in annually bleached corals? Coral Reefs DOI 10.1007/s00338-015-1390-z.

Liu G, Strong AE, Skirving W, Arzayus LF. 2006. Overview of NOAA coral reef watch program's near-real time satellite global coral bleaching monitoring activities. Proc. Int. Coral Reef Symp. 10:1783-1793.

Loya Y, Sakai K, Yamazato K, Nakano Y, Sambali H, van Woesik R. 2001. Coral bleaching, the winners and the losers. Ecol. Lett. 4:122-131.

Manly BFJ. 1991. Randomization, bootstrap and Monte Carlo methods in biology ( $2^{\text {nd }}$ ed.). London: Chapman \& Hall/CRC.

Marshall PA, Baird AH. 2000. Bleaching of corals on the Great Barrier Reef: differential susceptibilities among taxa. Coral Reefs 19:155-163.

McClanahan TR, Ateweberhan M, Muhando CA, Maina J, Mohammed MS. 2007. Effects of climate and seawater temperature variation on coral bleaching and mortality. Ecol. Monogr. 77:503-525.

McConney P. 2011. Coastal fisheries of Barbados in Coastal fisheries of Latin America and the Caribbean (eds Salas, S. et al.). FAO Fisheries and Aquaculture Technical Paper 544:49-71

McWilliams JP, Cote IM, Gill JA, Sutherland WJ, Watkinson AR. 2005. Accelerating impacts of temperature-induced coral bleaching in the Caribbean. Ecology 86:2055-2060.

Mumby PJ, Chisholm JRM, Edwards AJ, Andrefouet S, Jaubert J. 2001. Cloudy weather may have saved Society Island reef corals during the 1998 ENSO event. Mar. Ecol. Prog. Ser. 222: 209216.

Mumby PJ, Steneck RS. 2008. Coral reef management and conservation in light of rapidly evolving ecological paradigms. Trends Ecol. Evol. 23:555-563.

Mumby PJ. 1999. Bleaching and hurricane disturbances to populations of coral recruits in Belize. Mar. Ecol. Prog. Ser. 190:27-35. 
490

491

492

493

494

495

496

497

498

499

500

501

502

503

504

505

506

507

508

509

510

511

512

513

514

515

516

517

518

519

520

521

522

523

524

525

526

527

528

529

530

531

532

533

Nakamura T, van Woesik R. 2001. Water-flow rates and passive diffusion partially explain differential survival of corals during the 1998 bleaching event. Mar. Ecol. Prog. Ser. 212:301-304.

Nakamura T, Yamasaki H, van Woesik R. 2003. Water flow facilitates recovery from bleaching in the coral Stylophora pistillata. Mar. Ecol. Prog. Ser. 256:287-291.

Nurse LA, Charlery JL. 2016. Projected SST trends across the Caribbean Sea based on PRECIS downscaling of ECHAM4, under the SRES A2 and B2 scenarios. Theor. Appl. Climatol. 123:199-215.

Oliver TA, Palumbi SR. 2011. Do fluctuating temperature environments elevate coral thermal tolerance? Coral Reefs 30:429-440.

Otis DB, Carder KL, English DC, Ivey JE. 2004. CDOM transport from the Bahamas Banks. Coral Reefs 23:152-160.

Oxenford HA, Roach R, Brathwaite A, Nurse L, Goodridge R, Hinds F, Baldwin K, Finney C. 2008. Quantitative observations of a major coral bleaching event in Barbados, south eastern Caribbean. Climatic Change 87:45-49.

Oxenford HA, Roach R, Brathwaite A. 2010. Large scale coral mortality in Barbados: a delayed response to the 2005 bleaching episode. Proc. Int. Coral Reef Symp. 11:505-509.

Palumbi SR, Barshis DJ, Traylor-Knowles N, Bay RA. 2014. Mechanisms of reef coral resistance to future climate change. Science 344: 895-898.

Pandolf JM, Bradbury RH, Sala E, Hughes TP, Bjorndal KA, Cooke RG, McArdle D, McClenachan L, Newman MJH, Paredes G, Warner RR, Jackson JBC. 2003. Global trajectories of the longterm decline of coral reef ecosystems. Science 301: 955-958.

Pandolfi JM, Connolly SR, Marshall DJ, Cohen AL. 2011. Projecting coral reef futures under global warming and ocean acidification. Science 333:418-422.

Paris CB, Cowen RK, Lwiza ZMM, Wang DP, Olson DB. 2002. Multivariate objective analysis of the coastal circulation of Barbados, West Indies: implication for larval transport. Deep-Sea Research Part I-Oceanographic Research Papers 49: 1363-1386.

Rogers CS, Muller E, Spitzack T, Miller J. 2009. Extensive coral mortality in the US Virgin Islands in 2005/2006: a review of the evidence for synergy among thermal stress, coral bleaching and disease. Caribbean J. Sci. 45:204-214.

Rogers CS. 1985. Degradation of Caribbean and Western Atlantic coral reefs and decline of associated fisheries. Proc. Int. Coral Reef Symp. 5:491-496.

Schuhmann PW, Oxenford HA, Gill D, Staskiewicz T. 2011. Landings, costs, net profit and return on investment in two contrasting fisheries. Part 2: The nearshore trap fishery. Third project report on the economic valuation of fisheries in Barbados. Barbados: Fisheries Division, Ministry of Agriculture, Food, Fisheries, Industry \& Small Business Development. 45pp. http://www.cavehill.uwi.edu/cermes/docs/publications/schuhmann et al 2011 valuation of the trap fishery.aspx

Sprent P, Smeeton NC. 2001. Applied nonparametric statistical methods. Chapman \& Hall/CRC, New York.

Stansfield KL, Bowman MJ, Fauria SJ, Wilson TC. 1995. Water mass and coastal current variability near Barbados, West Indies. J Geophys Res 100: 24819-24830.

van Hooidonk R, Maynard JA, Liu Y, Lee, S-K. 2015. Downscaled projections of Caribbean coral bleaching that can inform conservation planning. Glob. Change Biol. 21:3389-3401. 
$534 \mathrm{R}$ Core Team. 2014. R: A language and environment for statistical computing. Austria: $\mathrm{R}$ Foundation for Statistical Computing, Vienna. http://www.R-project.org/. refugia in the sheltered bays of Palau: analogs of future reefs. Ecol. Evol. 2:2474-2484. Wagner DE, Kramer P, van Woesik R. 2010. Species composition, habitat, and water quality influence coral bleaching in southern Florida. Mar. Ecol. Prog. Ser. 408:65-78.

Wall M, Putchim L, Schmidt GM, Jantzen C, Khokiattiwong S, Richter C. 2014. Large-amplitude internal waves benefit corals during thermal stress. Proc. R. Soc. B. 282: 20140650.

West JM, Salm RV. 2003. Resistance and resilience to coral bleaching: implications for coral reef conservation and management. Conserv. Biol. 17:956-967.

Wilkinson C, Souter D. 2008. Status of Caribbean Coral Reefs after Bleaching and Hurricanes in 2005. Townsville: Global Coral Reef Monitoring Network, and Reef and Rainforest Research Centre.

Wooldridge SA. 2014. Formalising a mechanistic linkage between heterotrophic feeding and thermal bleaching resistance. Coral Reefs 33:1131-1136. 
550 Table 1. Summary statistics comparing the overall intensity of coral bleaching between 551 2005/2006 and 2010/2011 during the same survey months. The mean percent of bleached 552 colonies across the six sites (see Figure 2 for individual site values) and associated standard 553 deviation (in brackets) is given for each survey month and year. The results of the global

554 (incorporating all sites) median tests comparing the intensity of bleaching between years are 555 also shown (chi-square statistics and associated $\mathrm{p}$ values). For these tests, the transect data (as 556 percent of bleached colonies in a given transect) were used as replicates. $P$ values were 557 obtained by permuting transect data within sites (10,000 permutations) and were subsequently 558 adjusted to account for multiple tests (Holm, 1979). Bold font indicates statistical significance at 559 the 0.05 level.

560

561

562

563

564

565

566

567

568

569

570

571

572

573

\begin{tabular}{l|crrr} 
& \multicolumn{4}{|c}{ September/October } \\
Species & \multicolumn{1}{|c}{2005} & \multicolumn{1}{c}{2010} & Chi-square & p value \\
\hline Diploria strigosa & $\mathbf{5 9 . 4 ( 2 8 . 2 )}$ & $\mathbf{1 . 7 ( 1 . 9 )}$ & $\mathbf{2 0 . 3}$ & $\mathbf{0 . 0 0 1 5}$ \\
Montastraea cavernosa & $\mathbf{5 8 . 7 ( 3 0 . 9 )}$ & $\mathbf{1 2 . 4 ( 8 . 2 )}$ & $\mathbf{9 . 4}$ & $\mathbf{0 . 0 0 1 5}$ \\
Orbicella annularis & $\mathbf{8 0 . 6 ( 1 2 . 8 )}$ & $\mathbf{1 3 . 0 ( 1 3 . 2 )}$ & $\mathbf{3 0 . 1}$ & $\mathbf{0 . 0 0 1 5}$ \\
Siderastrea siderea & $\mathbf{6 5 . 0 ( 2 8 . 8 )}$ & $\mathbf{1 2 . 4 ( 1 4 . 7 )}$ & $\mathbf{2 2 . 3}$ & $\mathbf{0 . 0 0 1 5}$ \\
Porites astreoides & $\mathbf{5 2 . 4 ( 1 8 . 6 )}$ & $\mathbf{0 . 2 ( 0 . 3 )}$ & $\mathbf{5 6 . 1}$ & $\mathbf{0 . 0 0 1 5}$
\end{tabular}

574

575

576 
577 Table 2. Summary statistics comparing the intensity of post-bleaching coral mortality (across all 578 sites) between 2005/2006 and 2010/2011 using the same survey months. The mean percent of 579 recently dead tissue per colony across the six sites (see Figure 3 for individual site values) and 580 associated standard deviation (in brackets) is given for each survey month and year. The results 581 of the global (incorporating all sites) median tests comparing the intensity of tissue mortality 582 between years are also shown (chi-square statistics and associated $p$ values). For these tests, 583 the transect data (as mean percent of recently dead coral tissue per colony in a given transect) 584 were used as replicates. P values were obtained by permuting transect data within sites $(10,000$ 585 permutations) and were subsequently adjusted to account for multiple tests (Holm, 1979). Bold 586 font indicates statistical significance at the 0.05 level.

587

588

589

590

591

592

593

594

595

596

\begin{tabular}{l|rcrc} 
& \multicolumn{5}{|c}{ February } \\
Species & \multicolumn{1}{|c}{2006} & 2011 & Chi-square & p value \\
\hline Diploria strigosa & $\mathbf{2 . 7 ( 2 . 2 )}$ & $\mathbf{1 . 2 ( 1 . 3 )}$ & $\mathbf{6 . 9}$ & $\mathbf{0 . 0 2 7 5}$ \\
Montastraea cavernosa & $5.8(11.9)$ & $0.5(0.6)$ & 1.3 & 0.6840 \\
Orbicella annularis & $3.1(1.7)$ & $1.2(1.2)$ & 1.3 & 0.6840 \\
Siderastrea siderea & $2.0(0.8)$ & $1.2(1.2)$ & 0.8 & 0.6840 \\
Porites astreoides & $1.8(1.0)$ & $0.6(0.5)$ & 0.6 & 0.6840
\end{tabular}

\begin{tabular}{l|rcrr} 
& \multicolumn{5}{|c}{ June } \\
Species & \multicolumn{1}{|c}{2006} & 2011 & Chi-square & p value \\
\hline Diploria strigosa & $10.2(4.3)$ & $0.8(1.4)$ & 22.9 & 0.0010 \\
Montastraea cavernosa & $10.8(6.2)$ & $0.2(0.3)$ & 19.5 & 0.0010 \\
Orbicella annularis & $29.4(18.1)$ & $1.0(0.9)$ & 24.3 & 0.0010 \\
Siderastrea siderea & $13.8(7.2)$ & $4.5(5.4)$ & 22.3 & 0.0010 \\
Porites astreoides & $7.8(3.5)$ & $0.8(0.7)$ & 16.9 & 0.0010
\end{tabular}




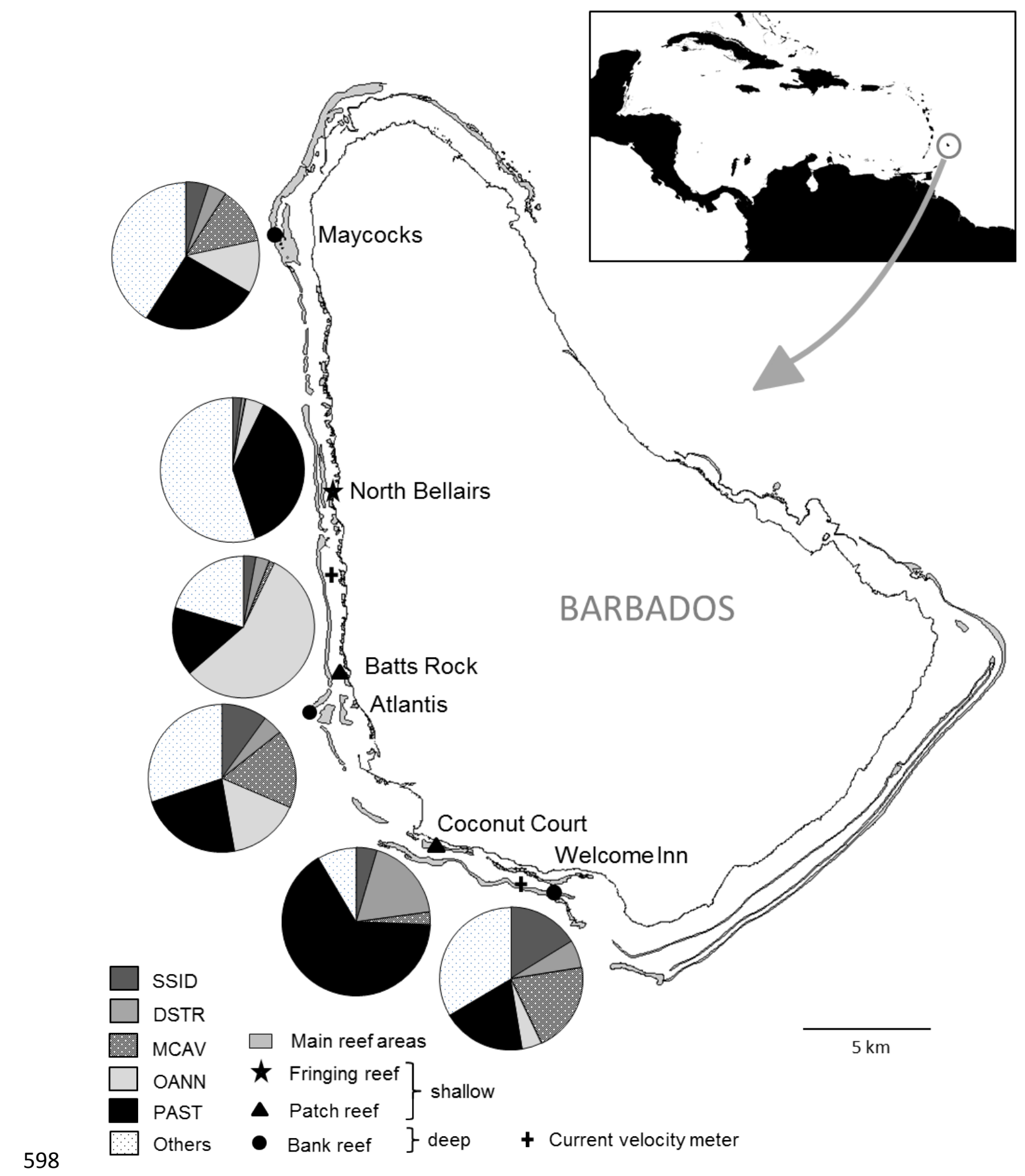

599 Figure 1. Map of Barbados indicating location and characteristics of the six reef sites surveyed, and the 600 two current velocity meters. Inset shows location of Barbados in the Caribbean. Pie charts show relative 601 abundance of the five selected dominant coral species at each site. SSID - Siderastrea siderea, DSTR 602 Diploria strigosa, MCAV - Montastraea cavernosa, OANN - Orbicella annularis, PAST - Porites 603 astreoides. 


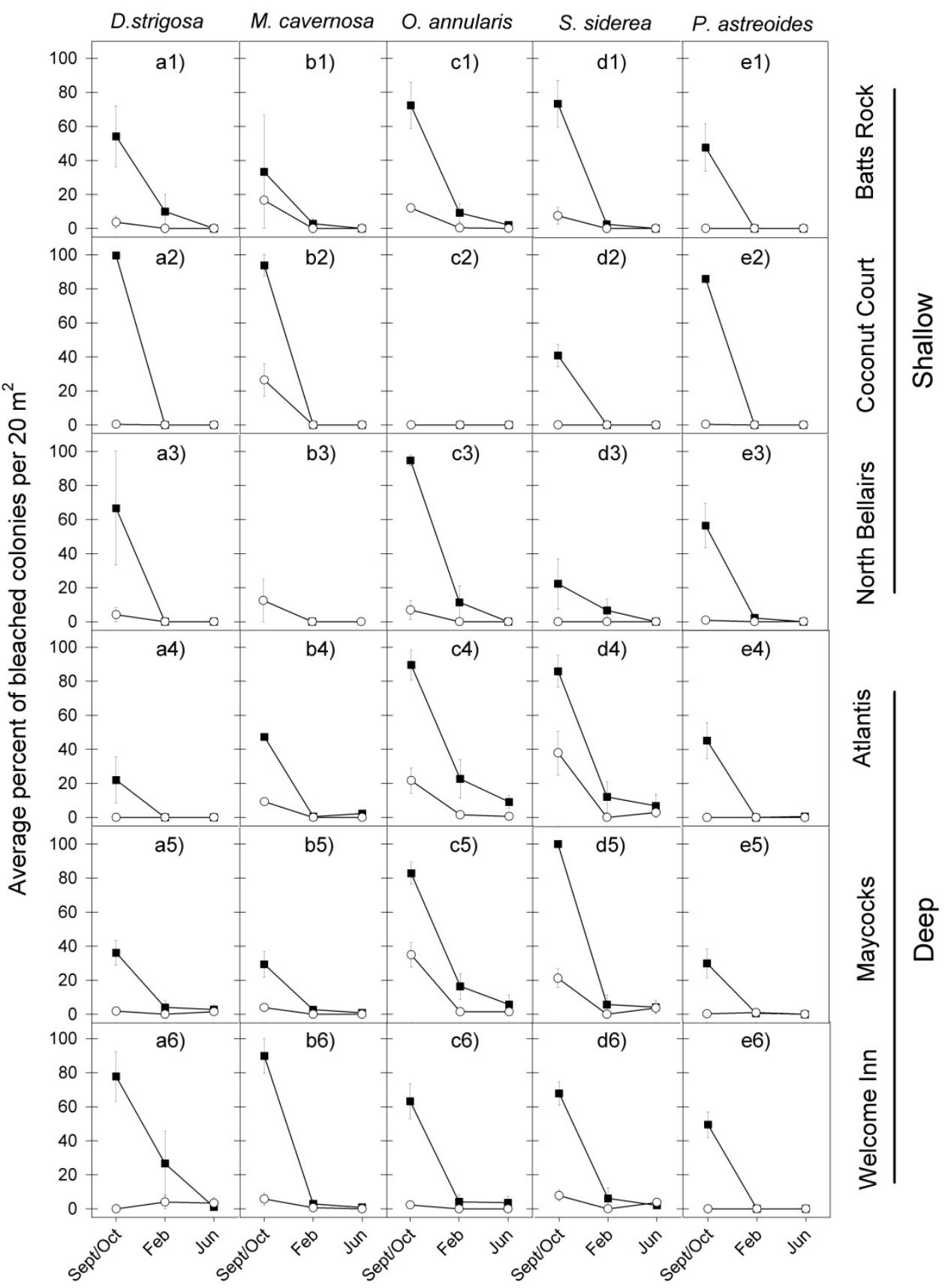

605

Survey period

606 Figure 2. Average percent of bleached colonies during peak bleaching (September/October) and the 607 following post-bleaching (February and June) survey periods in 2005-2006 (black squares) and 20106082011 (white circles) for the five selected dominant coral species (a-e) across the six study sites (1-6). 609 Error bars denote 1 standard error. Lack of symbols in b3 panel indicates that no $M$. cavernosa colonies 610 were sampled in Sept/Oct 2005 and in June 2006 at the North Bellairs site; and in c2 panel no $O$.

611 annularis colonies were sampled in Sept/Oct 2005 at the Coconut Court site. 


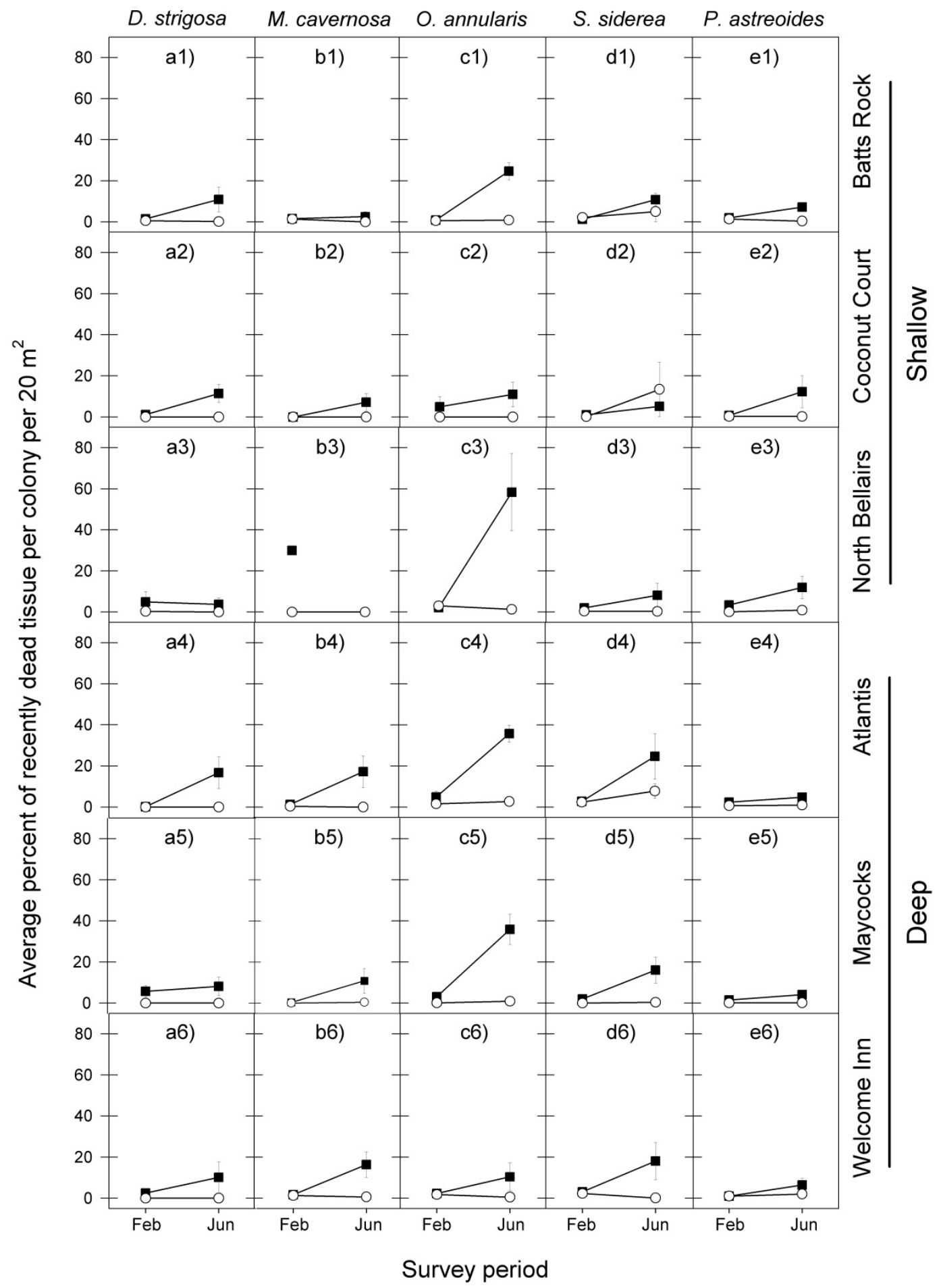

612

Survey period

613 Figure 3. Average percent of recently dead coral tissue per colony during the post-bleaching survey 614 periods (February and June) in 2006 (black squares) and 2011 (white circles) for the five selected 615 dominant coral species (a-e) across the six study sites (1-6). Error bars denote 1 standard error. Missing 616 symbol in b3 panel indicates that no $M$. cavernosa colonies were sampled at the North Bellairs site in 617 June 2006. 
A

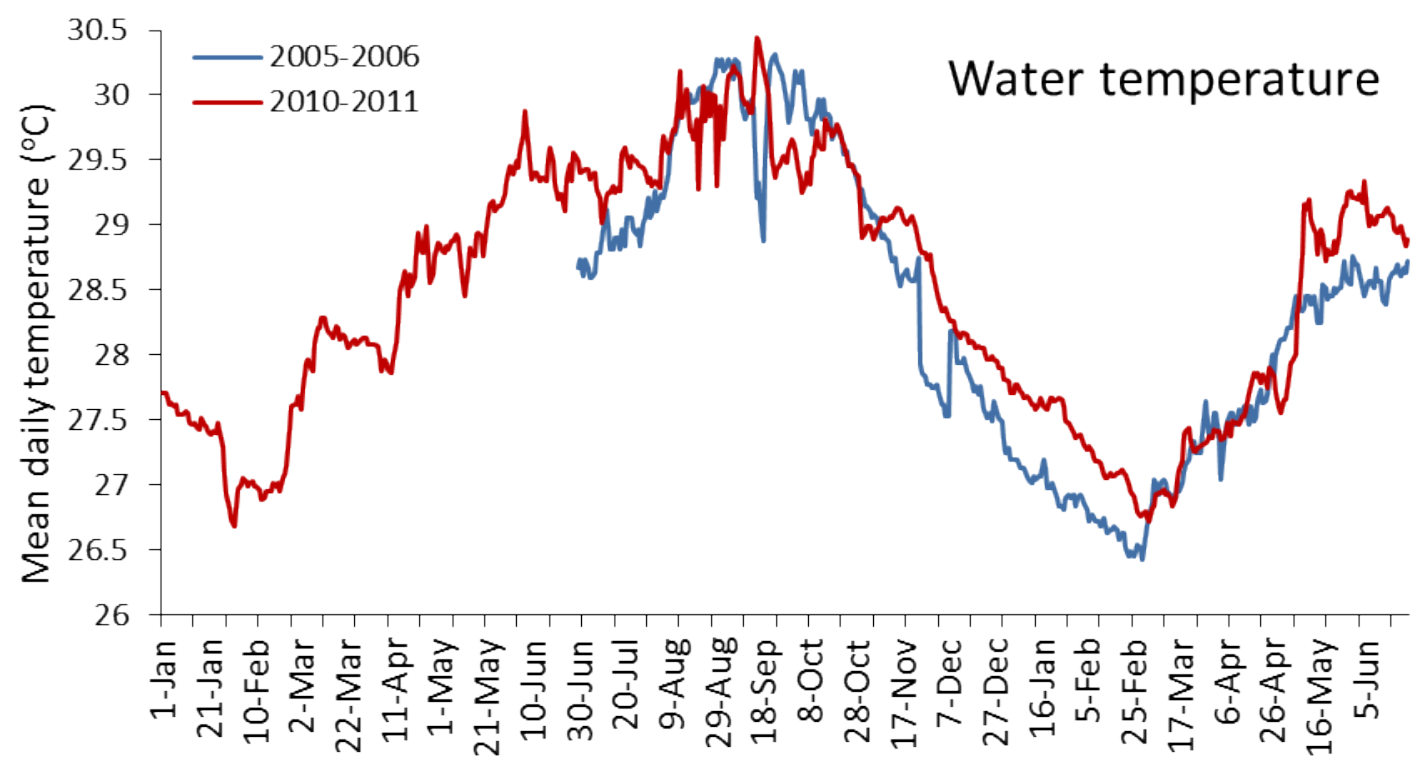

B

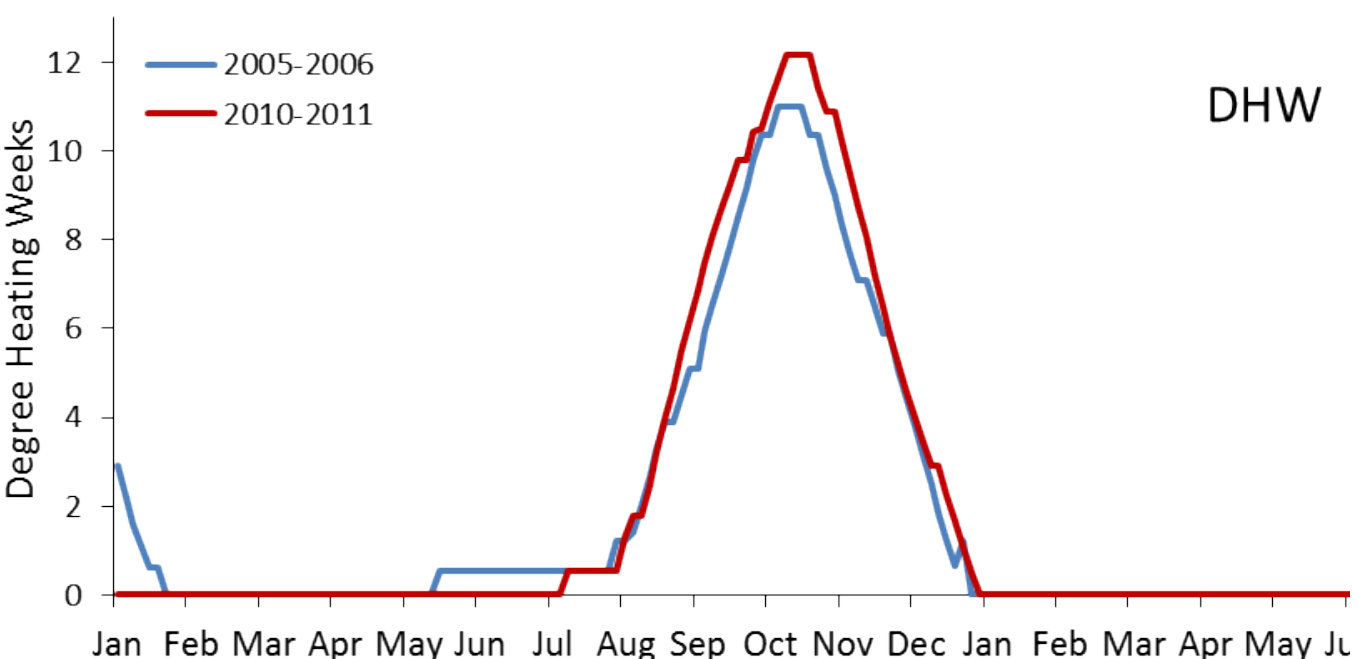
Jan Feb Mar Apr May Jun Jul Aug Sep Oct Nov Dec Jan Feb Mar Apr May J

Figure 4. Comparison of the temperatures experienced by coral reefs in Barbados during the 2005/2006 (blue line) and 2010/2011 (red line) mass bleaching events. Panel A) shows mean daily in situ water temperatures (data are only available from June 2005); panel B) shows satellite-derived accumulated heating stress as bi-weekly computed degree heating weeks

624 (http://coralreefwatch.noaa.gov/satellite/vs/data_timeseries/vs_ts_Barbados.txt). 

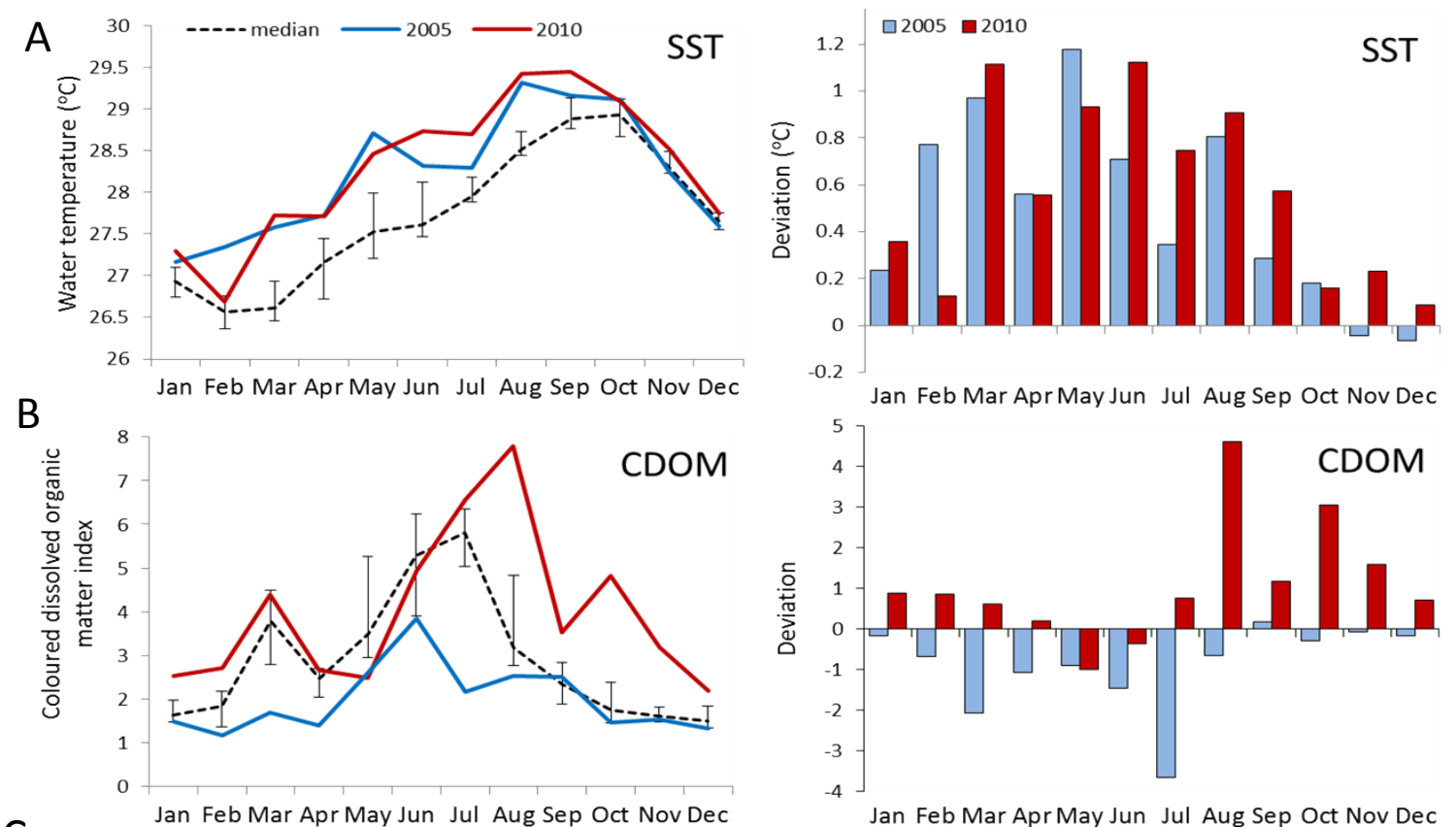

C
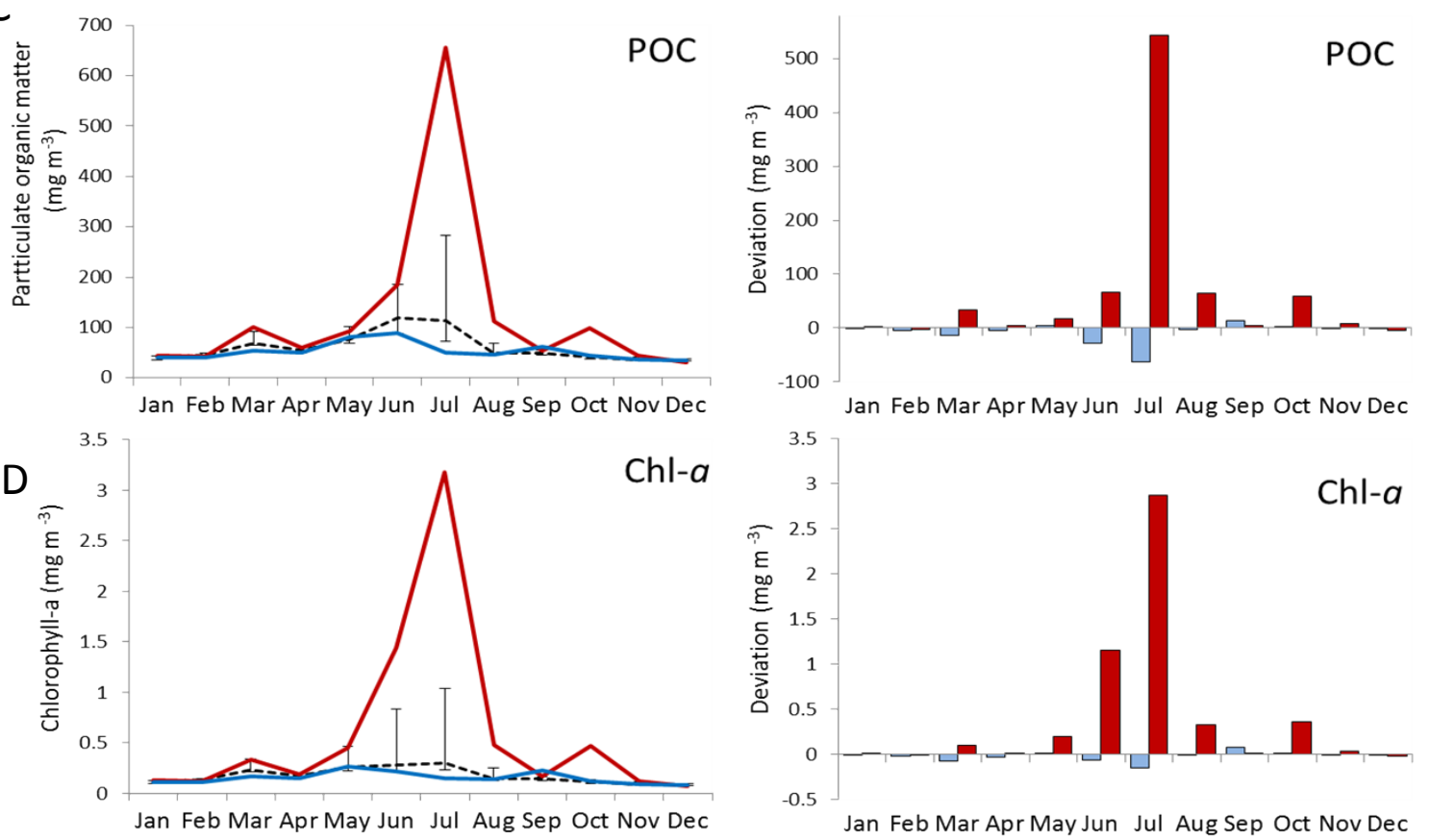

Figure 5. Comparison of environmental conditions experienced by coral reefs in Barbados during the 2005 (blue) and 2010 (red) warm water events. Data are from MODIS-Aqua satellite $4 \mathrm{~km}$ computed monthly means for (A) sea surface temperature (SST), (B) an index of coloured dissolved organic matter (CDOM), (C) particulate organic carbon concentration (POC), and (D) chlorophyll-a concentration in water surrounding Barbados (lat. $12.889-13.506^{\circ} \mathrm{N}$, long. 59.900,59.237 $\mathrm{W}$ ) (http://gdata1.sci.gsfc.nasa.gov/daac-bin/G3/gui.cgi?instance_id=ocean_month ). Left panel shows monthly means for both years and median values over an 8-year period (2003-2010) (black dashed line with bars indicating $1^{\text {st }}$ and $3^{\text {rd }}$ quartiles). Right panel shows a comparison of the deviation from the median values for 2005 and 2010. (Maps of time-averaged data for CDOM, POC and Chl-a, are given in Figures S1 and S2). 

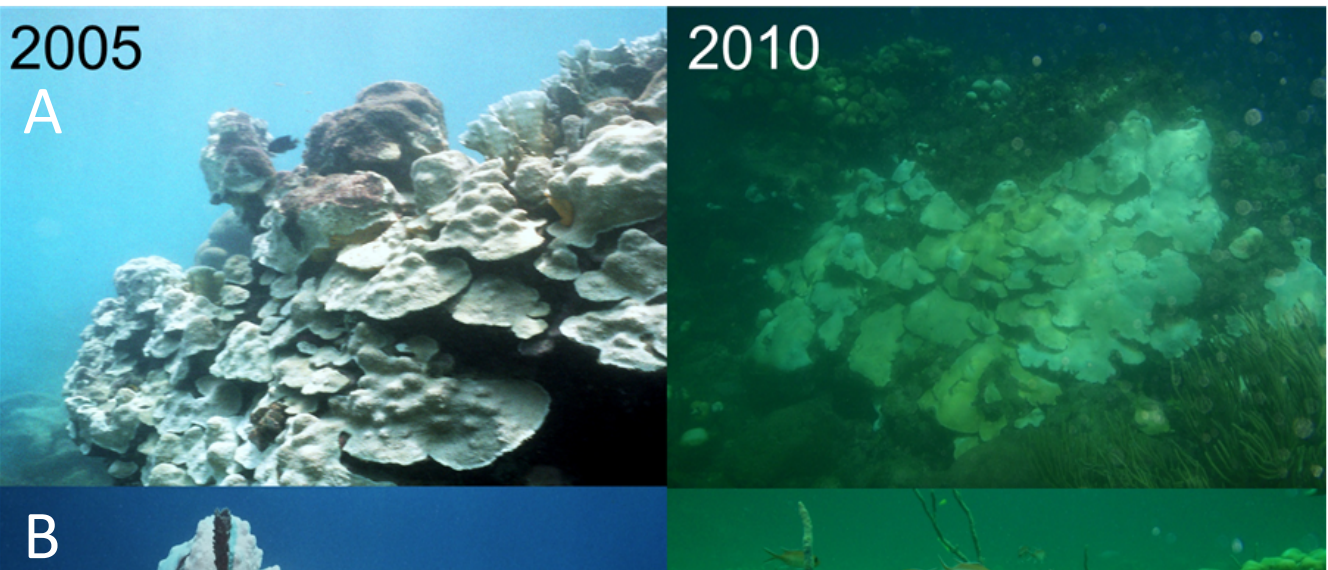

B
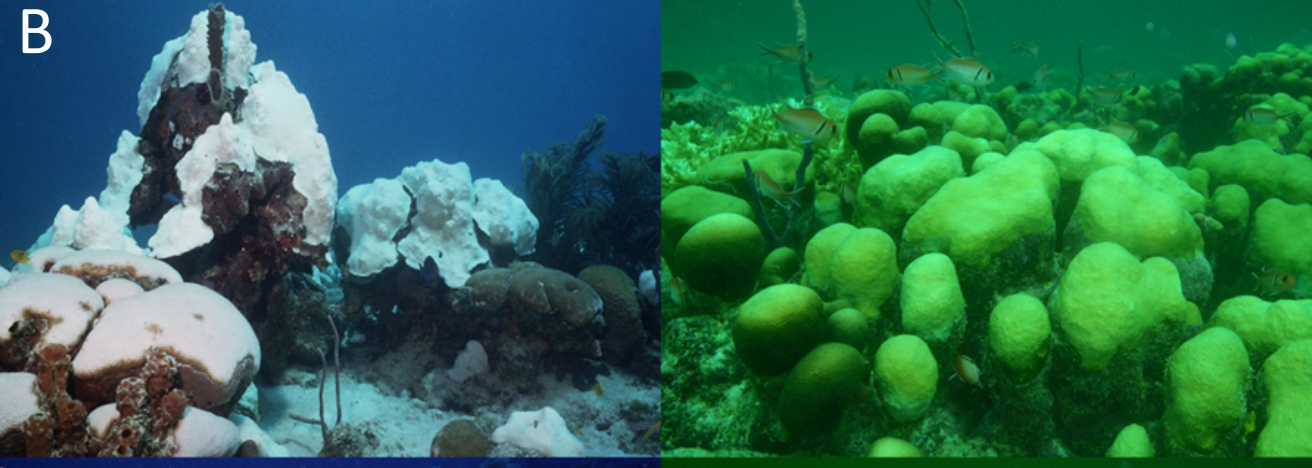

C
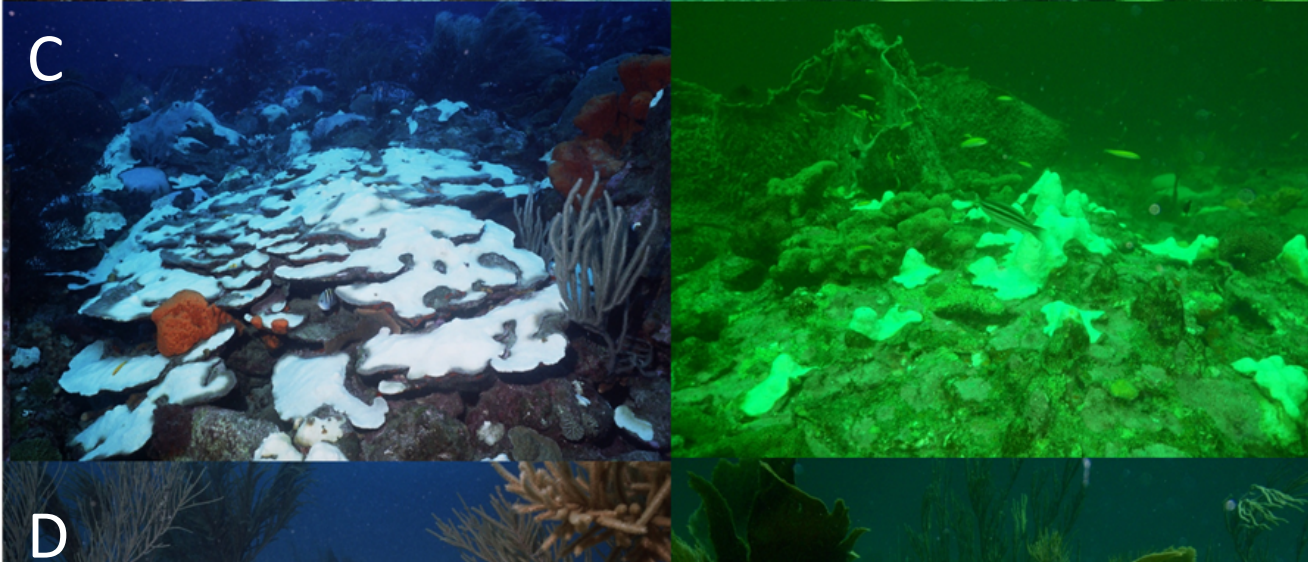

Figure 6. Photographs taken with the same camera, between $10 \mathrm{am}$ and $3 \mathrm{pm}$ during the coral

637 bleaching surveys in October of the two warm-water events in 2005 (left panel) and 2010 (right panel)

638 on Barbados reefs, showing the marked difference in water colour and light penetration. A - North

639 Bellairs fringing reef; B - Batts Rock patch reef; C - Atlantis bank reef; D - Coconut Court patch reef. 